\title{
PENGARUH SWISS BALL EXERCISE TERHADAP TINGKAT NYERI PADA PASIEN LOW BACK PAIN
}

\section{Yanti Susanti, Anwar Wardi Warongan dan Fitrian Rayasari}

Akper Buntet Pesantren Cirebon, Fakultas Ilmu Kedokteran Muhammadyah Jakarta dan Fakultas Ilmu Keperawatan Muhammadiyah Jakarta

Email: yantisusanti7261@gmail.com, anwarwardy@gmail.com dan

Fitrianrayasari@gmail.com

\section{Abstrac}

Low Back Pain (LBP) is a pain that is felt in the lower back region which is caused by various diseases and bodily activities that are not good. Swiss Ball Exercise is an exercise using swiss ball media aimed at reducing back pain, by increasing the strength of the abdominal muscles, glutea muscles, and back extensor muscles. The purpose of this study was to determine the effect of swiss ball exercise on the level of pain in the Pamengkang Health Center, Cirebon. Quasi experimental research design pre and post test with control group, using simple random sampling technique, a total sample of 38 patients consisting of 19 respondents in the intervention group and 19 respondents in the control group who suffered from low back pain. GLM-MR test results showed a decrease in pain levels after swiss ball exercise three times a week for one month with a trend of decreasing pain occurring at week $3(P=$ value $0,000, \alpha=0.05)$. The average reduction in pain level of the intervention group by 4,474 was smaller than the control group by 5,053. The author suggests that Swiss ball exercise can be applied as one of the nurses' independent interventions in improving the circulatory system, strengthening the lumbosacral muscles and the back muscles. Further the author needs to add research time to two months, to be able to assess the optimum point of time for the implementation of Swiss ball exercise as a nursing intervention.

Keywords: Swiss ball exercise; level of pain.

\section{Abstrak}

Low Back Pain (LBP) merupakan rasa nyeri yang di rasakan pada daerah punggung bagian bawah yang di sebabkan oleh berbagai penyakit serta aktifitas tubuh yang kurang baik. Swiss Ball Exercise adalah latihan dengan menggunakan media berupa bola swiss yang ditujukan untuk mengurangi nyeri bagian punggung belakang, dengan meningkatkan kekuatan otot-otot abdomen, otot glutea, dan otot ekstensor punggung. Tujuan penelitian ini adalah untuk mengetahui adanya pengaruh swiss ball exercise terhadap tingkat nyeri di Puskesmas Pamengkang Cirebon. Desain Penelitian quasi eksperimen pre and post test with control group, dengan menguunakan tehnik simple random sampling, total sampel 38 pasien yang terdiri dari 19 responden kelompok intervensi dan 19 responden kelompok kontrol yang menderita low back pain. Hasil uji GLM-MR adanya penurunan tingkat nyeri setelah dilakukan swiss ball exercise sebanyak 3 kali dalam satu minggu selama 
satu bulan dengan tren penurunan nyeri terjadi pada minggu ke 3 ( $\mathrm{P}=$ value 0,000 , $\alpha=0,05)$. Rata-rata penurunan tingkat nyeri kelompok intervensi sebesar 4,474 lebih kecil dibanding kelompok kontrol sebesar 5,053. Peneliti memberikan saran agar swiss ball exercise dapat diterapkan sebagai salah satu intervensi mandiri perawat dalam meningkatkan sistem peredaran darah, memperkuat otot-otot lumbosacral dan otot-otot punggung. Penelitian lebih lanjut perlu menambahkan waktu penelitian menjadi dua bulan, untuk dapat menilai titik optimum waktu pelaksanaan swiss ball exercise sebagai intervensi keperawatan.

Kata kunci: Swiss ball exercise; tingkat nyeri

\section{Pendahuluan}

Low Back Pain (LBP) di kenal dengan nyeri punggung bawah merupakan rasa nyeri yang di rasakan pada daerah punggung bagian bawah yang berasal dari tulang belakang daerah spinal, otot, syaraf atau struktur lain di sekitarnya, yang disebabkan oleh berbagai penyakit serta aktifitas tubuh yang kurang baik, serta merupakan gangguan dari sistem musculoskeletal yang paling representative (Schembri et al., 2014) (M, 2009) (Yan et al., 2014).

World Health Organization/WHO: 2009 menyatakan kira-kira 150 jenis gangguan muskuloskeletal di derita oleh ratusan juta manusia yang menyebabkan nyeri dan inflamasi yang sangat lama serta disabilitas atau keterbatasan fungsional, sehingga menyebabkan gangguan psikologik dan sosial. Nyeri yang diakibatkan oleh gangguan tersebut salah satunya adalah keluhan nyeri punggung bawah yang merupakan keluhan paling banyak ditemukan diantara keluhan nyeri yang lain (Navariastami et al., 2015) (Chung et al., 2013).

Nyeri merupakan perasaan tidak nyaman yang timbul oleh suatu hal, yang pada penerapannya hanya subjek penderita nyerilah yang dapat menjelaskan asal muasal dan/atau tempat dimana rasa nyeri itu timbul. Secara umum nyeri merupaan perasaan tidak nyaman yang umumnya memiliki kaitan dengan kerusakan jaringan tubuh atau faktor lain. untuk mengkaji dan mengidentifikasi nyeri klien, maka digunakan skala nyeri (Subandi, 2017).

Di Indonesia, penelitian yang dilakukan oleh Community Oriented Program for Controle of Rheumatic Disease/COPORD:2009 menunjukkan prevalensi nyeri punggung bawah $18,2 \%$ pada laki-laki dan13,6\% pada wanita (Rumiyati et al., 2019) Penelitian yang dilakukan kelompok studi nyeri PERDOSSI pada 14 rumah sakit pendidikan di Indonesia, pada bulan Mei 2002 menunjukkan jumlah penderita nyeri sebanyak 4.456 orang (25\% dari total kunjungan), dimana 1.598 orang $(35,86 \%)$ adalah penderita nyeri punggung bawah (Raghav \& Singh, 2017) (Lubis, 2003).

Penatalaksanaan konservatif LBP dapat diatasi dengan terapi non farmakologis, yaitu dengan menggunakan latihan atau exercise. Berbagai penelitian sudah dikembangkan untuk mengatasi nyeri yang di rasakan pasien low back pain dengan menggunakan bola swiss. Swiss ball adalah sebuah bola yang terbuat dari karet yang berbentuk bulat memiliki sifat lentur serta tidak mudah robek yang di gunakan sebagai 
tumpuan ketika melakukan peregangan baik pada kaki, otot leher, otot punggung atau pada bagian panggul (Rajan Balakrishnan \& Mahat, 2016).

Penelitian yang di lakukan yaitu exercise pada otot punggung dan perut dengan menggunakan media bola dan exercise ini dikenal swiss ball exercise. Data dari Puskesmas Pamengkang Cirebon menunjukan jumlah penderita dengan kasus neurologi bulan Oktober sampai dengan Desember tahun 2018 sebanyak 144 pasien. Kasus low back pain menenmpati urutan pertama, sebanyak 50 (34,7\%), di ikuti dengan Myalgia pada urutan kedua dengan jumlah penderita 40 (27,8\%), dan urutan ketiga adalah Hernia Nukleus Pulposus sebanyak $25(17,4)$, (Medikal Record Puskesmas Pamengkang Cirebon tahun 2018).

Survei pendahuluan yang di lakukan peneliti melalui observasi dan wawancara kepada kepala Puskesmas di Puskesmas Pamengkang Cirebon, dan kepada pasien puskesmas di temukan 7 dari 10 pasien yang mengalami low back pain 2 orang pasien mengalami nyeri sedang, 3 orang pasien mengalami nyeri berat, dan 2 orang pasien nyeri ringan. Selama ini untuk mengurangi nyeri menggunakan obat pereda nyeri yang di berikan oleh dokter dan 3 orang pasien yang di rujuk ke Rumah Sakit Pemerintah mereka melakukan fisioterafi jenis TEN. Sisanya sebanyak 7 orang pasien tidak melakukan fisioterapi, hanya berobat dan istirahat saja dan rata-rata mereka mengeluhkan nyeri punggung bawah 3-4 bulan, evaluasi nyeri yang dilakukan hanya menggunakan pertanyaan nyeri berkurang, bertambah atau tetap, tidak ada skala nyeri tertentu yang digunakan. Berdasarkan hasil wawancara dengan pasien low back pain, dampak dari kondisi nyeri yang di alami pasien low back pain dapat menyebabkan terganggunya kebutuhan dasar manusia di antaranya adalah pasien akan mengalami gangguan aktifitas dan istirahat, gangguan mobilisasi, gangguan personal hygiene kebutuhan dasar yang lainnya.

\section{Metode Penelitian}

Desain penelitian yang digunakan pada penelitian ini adalah quasi eksperiment pre and post with control group. Penelitian yang dilakukan adalah memberikan perlakuan pada kelompok intervensi. populasi dalam penelitian ini adalah semua pasien low back pain yang datang berobat di Puskesmas Pamengkang Cirebon sebanyak 144 orang. Sampel penelitian adalah pasien low back pain yang diambil secara simple random sampling, yaitu sebanyak 38 orang, terbagi 19 pasien kelompok intervensi dan 19 pasien kelompok kontrol.

Penelitian ini dilakukan di Puskesmas Pamengkang Cirebon. Pertimbangan pemilihan tempat penelitian ini karena Puskesmass ini memiliki populasi low back pain banyak, sehingga memungkinkan untuk memperoleh sampel sesuai dengan kriteria inklusi.

Penelitian ini dilaksanakan dimulai dari persiapan penelitian dan proposal diajukan pada bulan nopember-desember 2018, dan pengumpulan data akan dilakukan selama 1 bulan, yaitu pada maret-april 2019. Proses pengambilan dan pengumpulan data diperoleh dengan lembar kuesioner tingkat nyeri. Variable dalam penelitian ini adalah 
variabel independen yaitu swiss ball exercise, variable dependen tingkat nyeri pasien low back pain, variabel counfonding terdiri atas:usia, indek masa tubuh, jenis kelamin, jenis pekerjaan dan aktifitas olah raga.

Proses pengumpulan data dilakukan selama 1 bulan berturut- turut, Pada kelompok intervensi dan control, sebelum dilakukan intervensi terlebih dahulu semua di lakukan pengukuran tingkat nyeri, kemudian diukur kembali pada minggu ke pertama, kedua, ketiga dan keempat.

\section{Hasil dan Pembahasan}

\section{Karakteristik Responden}

Secara fisiologis, kemampuan otot wanita lebih rendah daripada pria. Selain itu, wanita dengan usia kisaran 41-50 yang mulai memasuki masa menopause terjadi penurunan hormon estrogen yang mengakibatkan kepadatan tulang berkurang sehingga beresiko terjadinya Low Back Pain. (Andini, 2016). Osteoporosis dapat mempermudah terjadinya fraktur disebabkan karena adanya penurunan dari matrik atau masa tulang sehingga proses mineralisasi dan kekokohan tulang menurun. Hal ini bisa mempermudah terjadinya fraktur vertebra terutama vertebra thorakalis, vertebra lumbalis. Fraktur vertebra dapat menyebabkan stenosis spinal, skoliosis dan kifosis. (Casey: 2010). Diperluat oleh penelitian Syafitry,:2016 yang mengatakan bahwa jumlah penderita low back pain pada wanita 66,7\% lebih tinggi jika di bandingkan dengan penderita low back pain laki-laki 33,3\%. Prevalensi terjadinya low back pain lebih banyak pada wanita dari pada laki-laki.

\section{Uji Multivariat}

Dengan Hasil penelitian ada pengaruh swiss ball exercise terhadap tingkat nyeri dengan rata-rata penurunan tingkat nyeri kelompok A sebesar 2,267 lebih kecil dibanding pada kelompok B sebesar 2,93.

Penelitian yang dilakukan oleh Balakrishnan tersebut mendukung penelitian pengaruh swiss ball exercise salah satunya dari pelaksanaan intervensi yang di lakukan selama 3 kali dalam satu minggu, berturut-turut selama 1 bulan tingkat nyeri mengalami penurunan, yang terjadi mulai pada minggu ke 3 setelah di berikan perlakuan swiss ball exercise. 


\section{Grafik 1}

Tren Penurunan tingkat nyeri antara kelompok intervensi dan kontrol n 38) pada pengukuran 1-5 di Puskesmas Pamengkang Cirebon Tahun 2019

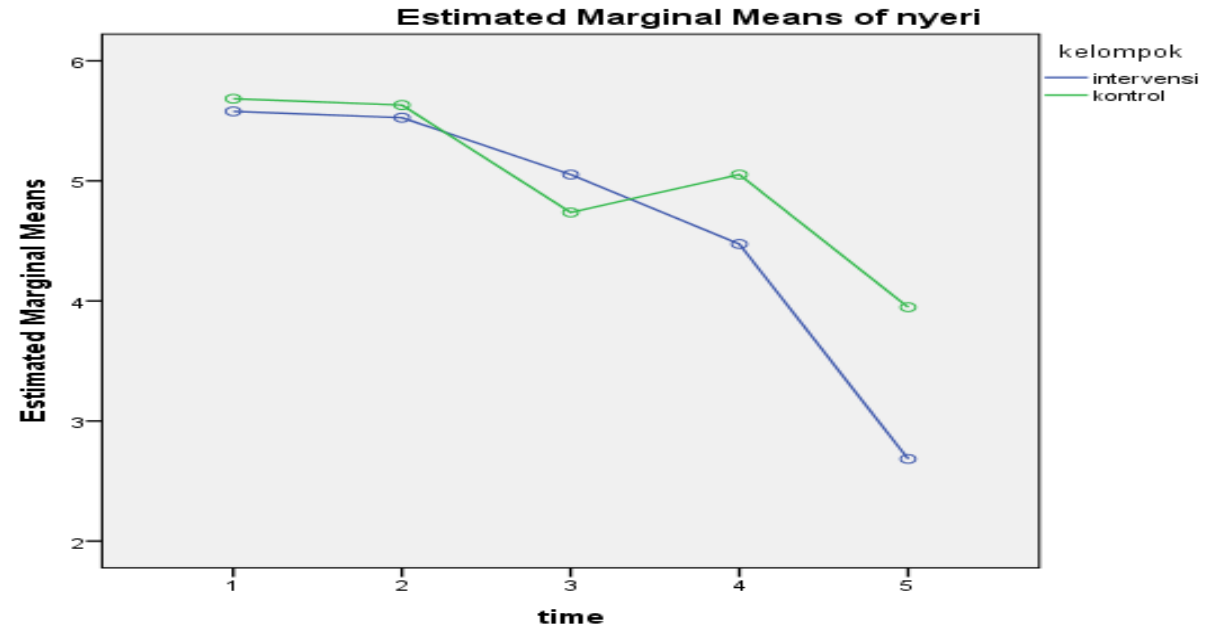

Pada tahapan pengukuran 1-5 tampak terjadinya penurunan nyeri yang dapat dilihat dari garis horizontal pada grafik plot yang masih terus menurun, terjadi penurunan nyeri yang signifikan pada pengukuran ke 3 .

\section{Kesimpulan}

Karakteristik responden berdasarkan usia terbanyak adalah $\leq 50$ tahun pada kelompok intervensi sedangkan pada kelompok kontrol > 50 tahun. Berdasarkan jenis kelamin perempuan merupakan kelompok terbanyak baik pada kelompok intervensi ataupun kelompok kontrol, berdasarkan indeks masa tubuh kelompok intervensi lebih banyak memiliki IMT>30 (52,6\%) di bandingkan dengan kelompok kontrol. Berdasarkan jenis pekerjaan kelompok kontrol lebih banyak yang beresiko $(89,5 \%)$ di banding kelompok intervensi sedangkan berdasarkan aktifitas olahraga kelompok kontrol lebih banyak pasien yang memiliki resiko sebanyak 14 (73,7\%) di bandingkan dengan kelompok intervensi. Ada pengaruh swiss ball exercise terhadap tingkat nyeri. 


\section{BIBLIOGRAFI}

Andini, Y. P. (2016). Pengaruh shari'ah compliance (kepatuhan shari'ah) dan pelayanan terhadap loyalitas nasabah Pt. Bprs Lantabur Tebuireng Cab. Mojokerto. UIN Sunan Ampel Surabaya.

Chung, S., Lee, J., \& Yoon, J. (2013). Effects of stabilization exercise using a ball on mutifidus cross-sectional area in patients with chronic low back pain. Journal of Sports Science \& Medicine, 12(3), 533.

Lubis, Z. (2003). Status gizi ibu hamil serta pengaruhnya terhadap bayi yang dilahirkan. Program Pascasarjana Institut Pertanian Bogor.

M, B. J. (2009). Keperawatan Medikal Bedah. Salemba Medika.

Navariastami, N., Koswara, H., Kep, M., \& Ningsih, N. (2015). Pengaruh Mckenzie Back Exercise Terhadap Skala Nyeri Punggung Bawah Pengrajin Songket. Jurnal Skolastik Keperawatan, 1(2), 44-51.

Raghav, S., \& Singh, A. (2017). Role of swiss ball exercises in reducing pain, disability and improving muscle endurance in patients with mechanical low back ache. Int $J$ Physiother Res, 5(2), 1966-1970.

Rajan Balakrishnan, E. Y., \& Mahat, M. F. Bin. (2016). Effectiveness of the core stabilisation exercise on floor and Swiss ball on individual with non-Specific low back pain. International Journal of Physical Education Sports and Health, 3(1), $347-356$.

Rumiyati, E., Anies, A., \& Kartini, A. (2019). Pengaruh Pemberian Jus Melon Terhadap Kadar Hemoglobin Ibu Hamil Yang Mengkonsumsi Tablet Fe Di Puskesmas Plupuh Ii Wilayah Kerja Dinas Kesehatan Kabupaten Sragen. School Of Postgraduate.

Schembri, L., Fenech, P., \& Sacco, M. (2014). Low back pain: A comparative study on the value of core training versus traditional strengthening exercises.

Subandi, E. (2017). Pengaruh Mobilisasi Dini Terhadap Tingkat Nyeri Pada Pasien Post Operasi Sectio Caesarea Di Ruang Melati Rsud Gunung Jati Kota Cirebon Tahun 2017. Syntax Literate; Jurnal Ilmiah Indonesia, 2(5), 58-74.

Yan, C.-F., Hung, Y.-C., Gau, M.-L., \& Lin, K.-C. (2014). Effects of a stability ball exercise programme on low back pain and daily life interference during pregnancy. Midwifery, 30(4), 412-419. 